\title{
Democratic impatience: Martin Luther King, Jr. on democratic temporality
}

\author{
Mario Feit \\ Department of Political Science, Georgia State University, Atlanta, GA 30302, USA. \\ mfeit@gsu.edu
}

\begin{abstract}
The intensifying speed-up of contemporary economic, social and political life troubles democratic theorists because they assume that democracy depends on patience. This article turns to Martin Luther King, Jr. to challenge democratic theory's temporal bias. I argue that King demonstrates that impatience, too, is a democratic virtue. Building on impatient knowledge, democratic impatience aides in overcoming undemocratic legacies, fosters democratic subjectivity and agency, ensures political accountability, and creates a more inclusive practice of democratic belonging. I furthermore show that King reveals the temporal sophistication of democratic impatience, thereby contradicting the prevailing interpretation of self-defeating instantaneousness. In particular, democratic impatience's temporal origins of centuries of injustice, human mortality, and the context of social acceleration provide a mature impetus for democratic action. Moreover, democratic impatience persists over time. On the one hand, it does so because injustice persists. On the other hand, democratic impatience contains within itself a subordinate operational patience. In other words, democratic impatience is always already somewhat 'patient.' King's democratic impatience therefore not only redresses democratic theory's shortcomings, but it also generates a renewed sense of democratic possibility in our age, as democratic impatience is well suited to help us in redressing the crises and injustices deepened or generated by social acceleration.

Contemporary Political Theory (2017) 16, 363-386. doi:10.1057/s41296-016-0062-2; advance online publication 15 September 2016
\end{abstract}

Keywords: Martin Luther King, Jr.; democracy; impatience; patience; social acceleration; time - political aspects

Democracy today faces a crisis - a crisis of temporality. In particular, we live in an age of social acceleration, that is, we are experiencing an intensifying speed-up of social, economic, and political life (Bauman, 2005; Connolly, 2002; Crary, 2013; Dean, 2010; Glezos, 2012; Harvey, 1990; Rosa, 2005, 2010; Scheuerman, 2004; Wolin, 1997). Causal explanations for this speed-up vary: capitalism, technological innovation, or mutually reinforcing combination of the two are cited as driving social acceleration. Whatever the precise causal explanation, a consensus has

(c) 2016 Macmillan Publishers Ltd. 1470-8914 Contemporary Political Theory Vol. 16, 3, 363-386 www.palgrave.com/journals 
emerged that social acceleration undermines democracy. While democracy putatively depends on slowness and patience, social acceleration increasingly does away with both. Democratic decision-making processes can no longer afford their requisite slowness and patience in the face of a faster-moving world and its proliferating problems (Scheuerman, 2004; Rosa, 2005, 2010). Perhaps worse, individuals are increasingly losing the capacity for patience, that is to say, they are losing the capacity for being democratic citizens (Crary, 2013, p. 124; Wolin, 1997; Dean, 2010, p. 125).

Responses to this crisis of democracy in the wake of social acceleration vary. Some lament the end of democratic possibilities in our present (Rosa, 2005, pp. 458-459; Wolin, 1997). Others call for a reconstitution of the patience we have lost; they seek to double down on the virtue of democratic patience (Agacinski, 2003, p. 142; Dean, 2009, pp. 46-47; Weiner, 2012, p. 140). Finally, some propose adapting democratic processes to greater speed (Scheuerman, 2004, pp. 187-224), or to help citizens learn to cope with speed (Connolly, 2002, pp. 144, 163-165). This last set of responses is productive in that it raises questions about the close association between democracy and patience. If we are indeed capable of adapting to or coping with greater speed, then perhaps democracy and patience are not synonymous. That said, we need to go further still and acknowledge democracy's partial affinity with speed. Social acceleration may in some respects equate to democratization, namely insofar 'a slow, homogenous world often supports undemocratic hierarchies' (Connolly, 2002, p. 144; also p. 143). If democracy, too, can entail speed, then impatience would join patience as a democratic virtue.

Indeed, I propose that democracy does only exclusively involve patience - but that democracy also at times calls for and is advanced by impatience. However, such a revaluing of democratic impatience can only proceed by way of overcoming democratic theory's bias in favor of patience. We need to locate and affirm the copresence of impatience at the heart of democracy. Doing so has not only the practical benefit of enabling a less alarmist reading of our present political condition; more importantly, we would also arrive at a more theoretically sound conception of democracy. To begin such a reconsideration of democratic theory and practice, I turn to Martin Luther King, Jr. I argue that King implicitly reflects on the temporality of democracy, and that he offers a robust understanding of impatience as a democratic virtue. Importantly, for King, democratic impatience that is, greater democracy - can thrive under conditions of social acceleration. To be clear, democratic impatience is not simply drawing on the benefits of social acceleration; democratic impatience thrives precisely because it responds to the dangers of social acceleration, namely how the increasing pace of life proliferates or deepens injustice.

Beyond this rethinking of democratic theory, I also turn to King for developing finer conceptual distinctions than the conventional, simplistic contrast between patience as virtue and impatience as vice (Callan, 1993; Kupfer, 2007). King 
reminds us that patience can also be a vice, namely when as imposed patience it results from and perpetuates racial injustice. Furthermore, he shows that impatience can be a virtue, namely when in the form of democratic impatience it advances democratic justice. Finally, King rejects the binary logic that casts patience and impatience as mutually exclusive opposites. Democratic impatience, too, endures across time and it, too, persists in the face of obstacles. Moreover, democratic impatience contains subordinate elements of operational patience in the form of strategic delays and long-term programs of transformation. To put it more bluntly, democratic impatience is always already somewhat 'patient.'

The ensuing conceptual retrieval draws on Martin Luther King, Jr.'s Why We Can't Wait and 'Letter from Birmingham City Jail.' ${ }^{1}$ To be clear, King's writing had a more immediate purpose than theorizing democratic impatience. However, I believe that precisely King's more immediately political motivations enable him to articulate a - however implicit - theory of democratic impatience. Indeed, had King undertaken a philosophical project of considering the merits of impatience, then he might have been sidelined by dominant religious, philosophical, and cultural traditions that devalue impatience. While I will reference some of this conceptual baggage, my focus will be on fleshing out the theoretical insights that spring from the democratic needs King gives voice to.

\section{On Democratic Patience}

When theorists of social acceleration worry about the contemporary loss of democratic patience, they are not misstating what democratic theory regards as the quintessential democratic temporality. In this section, I show that, notwithstanding their numerous disagreements, various approaches to democratic theory representative, deliberative, and radical - share the assumption that democracy depends on patience. Conversely, these divergent approaches agree that impatience undermines democracy. Far from constituting a theoretically sound consensus, democratic theory's endorsement of patience and condemnation for impatience amount to a bias, as will become clearer in my subsequent development of King's democratic impatience.

Representative theories of democracy assume patience in several ways. First, representative 'democracy has created a new political time, punctuated by elections' (Agacinski, 2003, p. 143). Citizens have to patiently wait for the next election to directly reshape government or public policy. They have to patiently endure that any desired changes may thus significantly lag behind potentially rapid changes in public opinion (Agacinski, 2003, pp. 141-142). Indeed, this temporal gap between political representation and (shifting) public opinion is presented as a strength of representative democracy, which rejects direct democracy's pursuit of immediacy (Urbinati, 2006, pp. 31-32, 90, 174; Agacinski, 2003, pp. 145-146). 
Second, representative democracy involves patience because it regards 'the relatively slow and deliberate character of legislative debates as constituting one of their virtues ... as a necessary precondition for ensuring its high quality' (Scheuerman, 2004, p. 39; Urbinati, 2006, pp. 196-198). There are several ways in which representative democracy seeks to slow down legislative processes. The very size and diversity of legislatures contributes to slowing down deliberation because 'debate within any but a tiny group ... is destined to be time-consuming solely because of its sequential character' (Scheuerman, 2004, p. 39; Agacinski, 2003, p. 173). Institutional requirements for committee hearings followed by several readings of draft bills before the entire legislature, too, delay representative democracy's decision-making. Additionally, bicameralism slows down lawmaking (Weiner, 2012, p. 44). Third, in its elitist variety, representative democracy favors the decision-making by patient elites over that of a putatively rash people. The Federalist Papers illustrate this idea. Representation empowers 'a chosen body of citizens... who will be the least likely to sacrifice [public welfare] to temporary or partial considerations' as they would be 'men who possess the most attractive merit, and the most diffusive and established characters' (Madison et al., 2005, pp. 52-53 - emphasis added). Due to their distinguished character, representatives would more likely side with 'reason' instead of 'the clamours of an impatient avidity for immediate and immoderate gain' (Madison et al., 2005, p. 230). This contrasts with 'pure democracy' in which fleeting popular passions hold sway (Madison et al., 2005, pp. 51, 54).

Deliberative democratic theory, meanwhile, endorses patience as a condition of good deliberation because, as Iris Marion Young explains, this theory 'assumes that participants in a decision-making process are not pressed for time, and that they can concentrate significant energies to their discussion' (Young, 2000, p. 33; emphasis added). The hope is that this would increase the odds in favor of just outcomes (Young, 2000, p. 35). This preference for patient deliberation may even be heightened for those whose 'ideal deliberation aims to arrive at a rationally motivated consensus' (Cohen, 1997, p. 75; Shapiro, 2002, p. 198). That said, deliberative democrats do not demand endless patience. They allow for majority decision-making - strictly speaking, an outside to deliberative democracy (Gutmann and Thompson, 2004, p. 18) - if, for example, 'there is no promise that consensual reasons will be forthcoming' (Cohen, 1997, p. 75). To be clear, the turn to voting does not abandon the presumption in favor of patient deliberation; it merely reduces the extent of patience that is practiced: instead of patient pursuit of maximally successful deliberation (justice or consensus) deliberative democrats at times make do with a lesser patience entailed in minimally successful deliberation (legitimacy of a majority decision in the eyes of the minority).

Patience is furthermore articulated as obligation for speakers and listeners. Speakers, for one, must patiently engage their interlocutors. Rather than rashly asserting preferences or preaching to the converted, they must take care 'to providing 
reasons that they sincerely expect to be persuasive to others' (Cohen, 1997, p. 76). Moreover, they must patiently endure and respond to critical questioning and pushback (Miller, 2012, p. 410). Listeners, too, must be patient; they should not 'be quickly dismissive of any argument ... that strikes a listener as nonpublic at first blush'; instead, they should 'make an effort to go beyond initial appearances and seek out public reasons in the presented views' (Morgan-Olsen, 2013, p. 189 - emphasis added). Although this duty to listen is especially pronounced for approaches that stress public reason, it generally applies to deliberative democratic approaches (Morgan-Olsen, 2013, pp. 189, 210). For Young, this obligation to patience especially pertains to those listening to victims of injustice (Young, 2000, p. 70).

Radical democrats, too, turn to democratic patience. First, patience is required for radical democracy because the latter remains 'far more aspiration that facticity' (Coles, 2008, p. 303). Patience is needed to endure the intervals between 'fugitive' moments of democracy (Wolin, 2008, p. 255; Grattan, 2014, p. 194). Indeed, the creation of radical democracy out of anti- or pseudo-democratic conditions requires patient persistence, not impatiently 'decisive action' (Coles, 2005, p. 69; Goodwyn, 1981, p. 47). For example, even 'Athenian democracy was not founded or established by a singular act. A long string of events, which included reverses as well as gains,' were required (Wolin, 1994, p. 35). Radical democracy thus demands patient, gradual transformation; indeed, it involves 'patiently seeking to translate bigger visions into littler packages in ways that will in turn heighten future possibilities for broader transformations' (Coles, 2005, p. 82). Though 'outrageous resistance' can be critical, it needs to be combined with everyday, slow and patient populism - otherwise, there is a danger of 'fizzling out' (Grattan, 2014, pp. 202-202, 192, 196). Second, a patient process of remaking the people is part and parcel of the development of radical democracy: 'The possibility of a demotic politics meant that over time submissive subjects might evolve into active citizens, into a different kind of being' (Wolin, 2008, p. 276; emphasis added). Those pushing for radicalization of the demos must - with 'democratic patience' - assist ordinary people in the difficult and slow process of overcoming their socialization and in developing democratic subjectivity (Goodwyn, 1981, pp. 49-50). In the present, this means 'invest[ing] in the more patient, constructive work of training neoliberal subjects how to be radical democratic actors' (Grattan, 2014, p. 189). Finally, radical democracy demands patience because '[d]emocratic deliberations ... are time-consuming' (Wolin, 1997, p. 4; 2008, p. 267). Radical democrats embrace patient deliberation due to an 'ethos that accents inclusion, dialogue, receptivity, equality, difference, a taste for ambiguity, patient discernment, and affirmation that political relationships centrally involve ongoing tension, some compromise, and humility in the face of disagreement' (Coles, 2008, p. 285). In other words, radical democracy involves patience because it cannot count on nor should it long for a spontaneously achieved or readily apparent popular will. 
From how these diverse approaches assume democratic patience, we can infer how they would reject impatience. All three approaches would agree that approaching deliberation with impatience leads to worse outcomes. Representative democrats would also be concerned about an impatient focus on the next election distracting us from the political present and its possibilities (Agacinski, 2003, p. 169). Alternatively, elitist approaches to representative democracy would worry about representatives becoming infected with ordinary people's impatience. Finally, radical democrats would add that impatience is self-defeating, because endurance and persistence are necessary for the creation of radical democracy.

\section{Against (Imposed) Patience}

From the previous section, it should be clear that democratic theory presents a formidable obstacle to appreciating impatience as a democratic virtue. However, King's democratic impatience has to contend with more than just democratic theory; given his deep roots in Christianity, he furthermore has to wrestle with the ways in which religion has devalued impatience. In this section, I argue that King replaces a religious understanding of patience with a political one, which simultaneously makes possible a way beyond democratic theory's praise of patience. In particular, King understands African Americans' patience under slavery and segregation not in religious but in political terms; this patience resulted from and was synonymous with oppression, which is why he rejects it as what I call imposed patience.

Christianity is critical for the conventional construction of a clear moral hierarchy between patience and impatience: "patience is the "basic constituent of Christianity," which [entails] ... "the power to wait, to persevere, to hold out, to endure to the end ..." (Lauber, 2010, p. 326; Garrett, 1999; Augustine, 1952; Tertullian, 1959). Jesus's life, suffering, and death exemplify patience as inherently moral. Conversely, Christianity regards impatience as sinful (Lauber, 2010, p. 327). According to this view, impatience is connected with selfishness: 'Those who live to expand themselves - their power, control, and influence - tend to be fearful and impatient. ... This life of selfish expansion, intent on instant success, results, and gratification is no life at all; it is a living death, which will come to naught' (Lauber, 2010, p. 325). In other words, impatience is not just immoral but also self-defeating.

Unsurprisingly, a focus on King's religious orientation leads to emphasizing patience in his thinking. For example, George Shulman notes: 'Against the "idolatry" of individualistic pleasure and conspicuous consumption, King endorses a left Puritanism to promote delay of gratification and dispositions to sacrifice for racial uplift' (Shulman, 2008, p. 118). Furthermore, Shulman points out that 'Black political struggles require a [distinct] perspective (on power, patience, suffering)' (Shulman, 2008, p. 98). While the latter could be understood in secular terms, Shulman regards it as inseparable from a theological perspective that identifies 
blacks with Hebrews as slaves in Egypt and exiles in Babylon' (Shulman, 2008, p. 107).

King, however, rejects patience by understanding it in - inverted - Roman rather than Christian terms. Admittedly, it would be possible to construe King's rejection of patience as stemming from Christianity itself - or, more accurately, to see it springing from what theologian Richard Fenn identifies as an alternative, active approach to waiting within Christianity (Fenn, 2001, pp. 69-71). Yet, even Fenn derives his appreciation of impatience from sociological observations rather than the Christian tradition (Fenn, 2001, pp. 65-66, 81, 86, 88, 91). Indeed, in emphasizing how power differentials are crucial for whether a group has to wait, King is closer to the Latin etymon patientia, albeit inverting the Roman valuation of this concept. Romans' assessment of patientia depended on a person's place in the social hierarchy. They believed that slaves' and women's inferior nature manifested itself in their patientia (Kaster, 2002, pp. 138, 140). Conversely, a free man's masculinity could be questioned by accusing him of patientia, although men with unquestioned power should display patientia toward their inferiors. That is, patience could be a virtue - unless it was too close for comfort to the assumed temperaments of slaves or women (Kaster, 2002, pp. 141, 143-144). In short, patientia was centrally about who had and who lacked power.

Similarly, King emphasizes power differentials when rejecting patience, which he generally only presents in terms of what I call imposed patience. Contrary to Christianity's redemptive understanding of patient suffering, King characterizes African American suffering during slavery and segregation as imposed patience - a patience that results from and is synonymous with injustice: 'The Negro had never really been patient in the pure sense of the word. The posture of silent waiting was forced upon him psychologically because he was shackled physically' (King, 1964, p. 27). While genuine patience would be self-chosen, injustice forces those suffering from it to endure imposed patience - which furthermore cements injustice. King does not pursue the distinction between genuine and imposed patience any further, nor does he endeavor to recover genuine patience. Importantly, he does not deem a moral form of patience, Christian or otherwise, relevant to the democratic politics he outlines.

Throughout Why We Can't Wait, King invokes patience as oppression, that is, as imposed patience. All his examples of patience are in fact instances of imposed patience. Even patient acts of self-liberation - slaves toiling away at night to save money to eventually buy their freedom - do not strike King as anything other than imposed patience. For the patient toil of those who purchased their freedom further indicts 'a system that bartered dignity for dollars' (King, 1964, pp. 126-127). Oppression forces the oppressed to be patient, whether simply for the sake of survival or for the limited avenues of liberation it permits.

Sadly, imposed patience did not end with the abolition of slavery but appears in new guises, such as moderates' appeals to slow down the civil rights movement to 
win white support. King rejects such gradualism because he perceives 'a terrible parallel between the outstretched and greedy hand of a slave trafficker who sold a Negro his own person, and' those calling for gradual reforms: 'What is implied here is the amazing assumption that society has the right to bargain with the Negro for the freedom which inherently belongs to him. Some of the most vocal liberals believe they have a valid basis for demanding that, in order to gain certain rights, the Negro ought to pay for them out of the funds of patience and passivity which he has stored up for so many years' (King, 1964, pp. 127-128 - emphasis added). For King, the patience of gradualism parallels the slave's patience - both are examples of imposed patience. To make African Americans wait was part and parcel of racial oppression - of racial time (Hanchard, 1999, pp. 253, 263-265) - because 'the nation had come to count on him as a creature who could quietly endure, silently suffer and patiently wait' (King, 1964, p. 16). Furthermore, King characterizes slow, piecemeal reforms as 'narcotics of delay [that] will dull the pain of progress' (King, 1964, p. 129) for those benefitting from an unjust status quo. Those who seek to impose patience on African Americans tellingly get to enjoy rather than suffer the status quo. Worse still, their "Wait" has almost always meant "Never"' (King, 1991b, p. 292). A patient pursuit of democratic justice would thus be tantamount to giving into imposed patience - to delaying democracy and justice indefinitely.

Perhaps unsurprising in light of the perniciousness of imposed patience - but stunning in relation to conventional views, whether rooted in religion or democratic theory - King goes as far as to assert that impatience rather than patience sustained African Americans over time: 'The result has been a demeanor that passes for patience in the eyes of the white man, but covered a powerful impatience in the heart of the Negro' (King, 1964, p. 28). Importantly, King here links impatience with persistence, self-preservation and with the ability to deceive oppressors. Impatience, contrary to prevailing definitions, was not self-defeating. African Americans were impatient yet not rash: as strategic actors, they bided their time while remaining impatient. King here refuses to contextualize African American suffering in Christian terms: impatience, not patience, is in the heart - and King does not regard it as a sin, but as a justified disposition in the face of oppression. Moreover, this persistent impatience runs counter to conventional classifications according to which impatience is a passing state (that has potentially damning long-term effects). Instead, the democratic impatience described by King is a persistent state - as long as injustice persists. That is, democratic impatience is more akin to an enduring 'mood' (Svendsen, 2005, p. 110) than to a passing 'vehement passion' (Fisher, 2002).

In developing a political rejection of patience, King not only sidelines religion's hold over our valuation of patience, he furthermore challenges democratic theory. In particular, King would question radical democrats' contention that patience is required to endure and overcome democracy's absence. For King, oppression sustains itself by way of imposed patience; in fact, the difference between patience (as hope or gradual change) and imposed patience is negligible under such 
circumstances. Democratic impatience, on the other hand, sustained African Americans during oppression. Far from being self-defeating, such democratic impatience was strategic and persistent, that is, helped lay the groundwork for future democratic transformation.

\section{Putting the 'Democratic' in Impatience}

Democratic theory regards impatience as a failure - a failure to muster patience, and thus a failure of democracy. From the perspective of democratic theory, impatience may well be an empirical reality but never a democratic ideal. However, in rejecting imposed patience, King indicates the extent to which patience may be an obstacle to the pursuit of democracy under non- or pseudo-democratic conditions. For patience to exclusively foster democracy - for it to be free of any vestiges of imposed patience - political reality would need to perfectly enact democratic ideals. Absent such ideal conditions, then, impatience is not a failure of democracy but necessary for democratization. In the following, I elaborate on some of the key features that distinguish democratic impatience. This is necessary to avoid conflating democratic impatience with other kinds of impatience, some of them quite apolitical, as King illustrates with many Americans' eager anticipation of escapist summer vacations, despite the suffering in their midst (King, 1964, p. 15). More importantly, I show how King's democratic impatience achieves the same democratic ends that democratic theory otherwise expects from patience.

As noted before, deliberative and radical democrats consider patience necessary for democratization: we need to patiently deliberate to move beyond entrenched perspectives, or to patiently persist with precarious democratic transformation. King, on the other hand, identifies democratic impatience as the catalyst of democratization because it accelerates political transformation. King likens the civil rights movement to other democratic revolutions when he calls it 'America's third revolution' or when he invokes the French Revolution and the Chartist movement (King, 1964, pp. 15-16). The latter two in particular resonate with a sense of democratic speed, which for King applies to revolutionary movements of social justice: 'a submerged social group, propelled by a burning need for justice, lifting itself with sudden swiftness, moving with determination and a majestic scorn for risk and danger, created an uprising so powerful that it shook a huge society from its comfortable base' (King, 1964, p. 16). Crucially, the oppressed reject imposed patience when they 'proclaim the unendurability of their oppression' (King, 1964, p. 16). Thus, 'This Revolution is genuine because it was born from the same womb that always gives birth to massive social upheavals - the womb of intolerable conditions and unendurable situations' (King, 1964, pp. 131-132). That is, democratic impatience does not come out of nowhere. It is a response to a history of imposed patience. 
Contrary to democratic theory's emphasis on patiently developing compromise in the name of democratic progress, democratic impatience enacts an uncompromising approach to justice because the undemocratic status quo maintains itself by way of compromise. Indeed, King points to the many compromises that perpetuated the suffering of African Americans: the Declaration of Independence did not include its original condemnation of the King's support for slavery; the Missouri Compromise; the end of Reconstruction; and Plessy v. Ferguson (King, 1964, p. 131). Consequently, for African Americans, "the word "compromise" is profane and pernicious' (King, 1964, p. 131). In response to the suggestion that maybe a more patient approach to political change would be wiser, King insists 'that the time is always right to do what is right' (King, 1991c, p. 354). Justice, hence, is inherently impatient. Delay is suspect because it puts off to the future what should be fully realized in the present.

King furthermore challenges democratic theory by arguing that impatience affirms the dignity of the oppressed, thereby remaking them as democratic subjects and agents. Not patient listening to the marginalized (deliberative democracy) or a patient remaking of the people (radical democracy) but democratic impatience manifests and facilitates democratic subjectivity. King illustrates this when discussing how for civil rights protesters an arrest became 'a badge of honor. The Revolution of the Negro not only attacked the external cause of his misery, but revealed him to himself. He was somebody. He had a sense of somebodiness. He was impatient to be free' (King, 1964, p. 30; emphasis in original). That is, democratic impatience is not simply politically significant because it has the potential to overcome an undemocratic status quo by way of speeding up social transformation. Critically, democratic impatience facilitates a new sense of self. Dignity, agency, and democratic impatience are mutually constitutive.

While one version of representative democracy puts its trust in patient elites' capacity to restrain a rash demos, King's democratic impatience offers a very different model of representation:

the command post was in the bursting hearts of millions of Negroes. When such a people begin to move, they create their own theories, shape their own destinies, and choose the leaders who share their own philosophy. A leader who understands this kind of mandate knows that he must be sensitive to the anger, the impatience, the frustration, the resolution that have been loosed in his people. Any leader who tries to bottle up these emotions is sure to be blown asunder in the ensuing explosion. (King, 1964, p. 132; emphasis added)

Contrary to representative democracy, King embraces the role of representing democratic impatience. When ordinary people impatiently seek democratic justice or when they challenge representatives' patience, they do not undermine democracy but strengthen it. Properly understood, democratic leadership gives voice to ordinary people's democratic impatience - and should be accountable to it. 
For democratic theorists, patience fosters a transcending of partial perspectives, and thus helps to create a more inclusive democratic community. King, on the other hand, believes that democratic impatience performs this task. For one group to enact its democratic impatience not only addresses its particular grievances, but furthermore opens up democratic possibilities for others: 'The Negro in winning rights for himself produces substantial benefits for the nation. ... Eventually the civil-rights movement will have contributed infinitely more to the nation than the eradication of racial injustice. It will have enlarged the concept of brotherhood to a vision of total interrelatedness' (King, 1964, pp. 151-152). Importantly, King proposes that different groups' particular forms of democratic impatience overlap: 'Labor, which made impatience for long-delayed justice for itself a vital motive force, cannot lack understanding of the Negro's impatience' (King, 1991a, p. 204). While this particular example could be explained with the intersectionality of race and class oppression (King, 1991a, p. 203), King instead makes a broader point: any particular instance of democratic impatience, as rooted as it is in specific forms of injustice, has the potential for affinity with other democratically impatient movements.

Finally, democratic impatience has the potential to transform those who are neither aggrieved nor initially at odds with the undemocratic status quo. King therefore offers a way of overcoming indifference, ignorance or prejudice, which differs from the patient dialogue otherwise deemed crucial - especially by deliberative democrats. In particular, as Edward Berry points out, the most famous sentence of the 'Letter from Birmingham City Jail,' which spans about a page as it lists one wrenching example of the evils of segregation after another (King, 1991b, pp. 292-293; 1964, pp. 81-82), "not merely states but enacts the experience of impatience by drawing the reader into the daily meaning of segregation for what seems an interminable length of time' (Berry, 2005, p. 117). King makes readers feel and thereby share in African Americans' democratic impatience. Yet, this goes beyond a rhetorical strategy, as civil rights protests visualize democratic impatience - especially in the television age (King, 1964, pp. 124-125) - and thus invite others to share in it. Not only patient deliberation but also an impatiently vicarious experience of others' suffering moves individuals toward more just perspectives.

\section{Impatient Knowledge}

As the preceding section showed, democratic impatience has the potential to accomplish central democratic ends: democratization, justice, subjectivity, accountability, solidarity as well as a willing surrender of undemocratic privilege. Nevertheless, many democratic theorists would worry that democratic impatience foregoes the slow-moving deliberation that they deem critical for the development and sharing of knowledge. Indeed, representative, deliberative, and radical democrats agree that only patient deliberation can lead to informed decision- 
making. Even if these democratic theorists were to acknowledge that a vicarious experience of others' democratic impatience can be just as good for sharing knowledge, they would nevertheless question how democratic impatience develops such knowledge without patient, critical exchange. When King praises democratic impatience for being uncompromising, democratic theorists would furthermore ask whether intransigence harbors a danger of mistaking self-righteousness for a thorough understanding of social problems.

King, on the other hand, rejects the notion that taking more time prepares better understanding: 'It is the strangely irrational notion that there is something in the very flow of time that will inevitably cure all ills. Actually time is neutral' (King, 1991b, p. 296). For patient deliberation to actually advance knowledge presupposes ideal conditions for deliberation, such as keeping an open mind. However, African Americans faced opponents who were intent on postponing any and all deliberation, let alone patient deliberation: 'Too long has our beloved Southland been bogged down in the tragic attempt to live in monologue rather than dialogue' (King, 1991b, p. 292). King here not only thinks of those with 'stubborn resolve to maintain the status quo' (King, 1964, p. 97); worse are white moderates who privilege order and gradual change over understanding: 'Shallow understanding from people of good will is more frustrating than absolute misunderstanding from people of ill will' (King, 1991b, p. 295). The problem, then, is not moderates' unwillingness to act on principles but their unwillingness to reach a deep understanding of those principles - principles that were clearly articulated 'centuries ago' in the Declaration of Independence and US Constitution (King, 1964, p. 32). If US history were viewed as an extended deliberation on these founding documents, and in light of the fact that as late as 1963 white moderates are only capable of a 'shallow understanding' of democracy and justice, then we can clearly see the limits of patient deliberation.

Democratic impatience, on the other hand, advances understanding in the absence of ideally democratic conditions: 'Just as Socrates felt that it was necessary to create a tension in the mind so that individuals could rise from the bondage of myths and halftruths to the unfettered realm of creative analysis and objective appraisal, we must see the need of having nonviolent gadflies to create the kind of tension in society that will help men to rise from the dark depths of prejudice and racism to the majestic heights of understanding and brotherhood' (King, 1991b, p. 291). Democratic impatience creates a political crisis that constitutes an epistemically beneficial crisis. Not further patient deliberation but democratic impatience makes it possible to move individuals from a shallow to a deeper understanding of democracy and justice. Because of democratic impatience's essential role in sharing this deep understanding, I refer to it as impatient knowledge.

Impatient knowledge warrants its name not simply because it is shared as a result of a politico-epistemic crisis produced by democratic impatience. It also has a deep connection to impatience in terms of how this knowledge develops in the first place. In particular, it is a form of knowledge the democratically impatient would

(c) 2016 Macmillan Publishers Ltd. 1470-8914 Contemporary Political Theory Vol. 16, 3, 363-386 
prefer not to have because it is accrued based on unjust suffering, based on imposed patience. They know too well - which is why they are impatient, that is, why they want to undo the conditions that made them live under and thus know this injustice. King illustrates this idea in the opening of Why We Can't Wait. He describes an African American boy in Harlem and an African American girl in Birmingham, who live in poverty and are surrounded by despair as the result of racial injustice. Both children understand that they inherited racial injustice. Moreover, both know the real history of the US, which is rife with oppression, exploitation, brutalization, and which does not acknowledge African American achievements or contributions. As King explains, these children also have a profound sense of their political present - of progress in decolonization as well as of the entrenched resistance to racial equality in the US (King, 1964, pp. ix-x). Unlike white moderates, those suffering from imposed patience understand their current situation and the rights denied to them. Their impatient knowledge would not be improved or corrected by patient deliberation; indeed, patient deliberation would only serve to diminish the fullness of its understanding. In being uncompromising, the democratically impatient only strengthen good democratic decision-making.

One reason why its defenders champion patient deliberation is that it refines our knowledge - not only by reducing errors but also by developing more nuanced, subtle, and complex understanding of any subject matter. Impatient knowledge, on the other hand, rejects this pursuit of refinement - not only because it prolongs suffering but also because refinement does not actually advance our understanding of injustice. Conversely, impatient knowledge is truer precisely because it eschews nuance, subtlety, or complexity. For example, King argues that 'the centennial [of Emancipation] only served to remind the Negro that he still wasn't free, that he still lived a form of slavery disguised by certain niceties of complexity. ... actual conditions had left him behind in the shadow of political, psychological, social, economic and intellectual bondage'; moreover, the difference between the South and the North on this was only that in the latter the injustice that 'confronted him was in hidden and subtle disguise' (King, 1964, p. 23). Similarly, King considers it irrelevant that there might be subtle differences among Southern elected officials: 'While Mr. Boutwell is much more articulate than Mr. Connor, they are both segregationists, dedicated to the task of maintaining the status quo' (King, 1991b, p. 292). King's impatient knowledge equates segregation with slavery, North with South, and moderates with rabid segregationists. Disregarding possible qualifications makes impatient knowledge more true - and more useful for pursuing democratic transformation.

\section{Temporal Origins}

Conventionally understood, impatience denotes a temporal deficiency: subjects fail in realizing their objectives because they do not wait. While this temporal failure 
may be absolute (not waiting at all) or relative (not waiting a sufficient amount of time), such a distinction ultimately does not matter to the charge that impatience necessarily fails. Not waiting long enough amounts to the same as not waiting at all because either putatively ends in failure. Given this assumption of temporal deficiency, discourses of patience do not distinguish among various impatient temporalities. Indeed, the presumption lingers that impatience describes subjects who are caught in the moment. Impatience, in other words, has neither past nor future tenses, nor does it have any duration: it is of the present tense alone.

King's democratic impatience, on the other hand, provides a more variegated and robust account of its temporalities - both of its origins and of its persistence. While later on I elaborate on democratic impatience's already noted temporal endurance, in this section I explicate three temporal origins of democratic impatience: centuries of injustice, our mortal condition, and social acceleration.

\section{Centuries of Injustice}

Why We Can't Wait contains a rightfully indignant refrain, namely the repeated description of centuries-long suffering: 'for two hundred years, without wages, black people' were enslaved and forced to build this country (King, 1964, p. x). Beyond exploitation and brutalization, King notes the 'three hundred years of psychological slavery' (King, 1964, p. 111) and how African Americans' 'pride and honor ... had been stripped from them over the centuries' (King, 1964, p. 40). Indeed, 'one hundred years after emancipation he lived on a lonely island of economic insecurity in the midst of a vast ocean of material prosperity' - with African American poverty a direct result of segregation (King, 1964, p. 23). This prolonged oppression depended on whites' indifference: 'For hundreds of years the quiet sobbing of an oppressed people had been unheard by millions of white Americans' (King, 1964, p. 112).

Throughout these centuries of suffering, African Americans had cause to be democratically impatient. King, however, identifies the crystallizing effect of the centennial of Emancipation, which makes visible both the centuries-long suffering and that it is ongoing: 'This was his recognition that one hundred years had passed since emancipation, with no profound effect on his plight' (King, 1964, p. 22). As King notes, 'Equality had never arrived. Equality was a hundred years late' (King, 1964 , p. x). As it exacerbated existing frustration, the anniversary of the Emancipation Proclamation therefore 'awoke [African Americans] from a stupor of inaction' (King, 1964, p. 25). It reminded them that the US needed 'to catch up with the basic rights [they] ought to have inherited automatically, centuries ago, by virtue of [their] membership in the human family and [their] American birthright' (King, 1964, p. 32).

But democratic impatience does not simply reject past centuries of injustice, it also refuses future centuries of injustice. The aftermath of Brown v. Board of 
Education gives rise to this anticipatory dimension of democratic impatience. Given the delaying tactics by opponents of school integration, King calculates that it would take until 2054 - a full century - before school integration would be accomplished, which would see many more generations of African Americans subjected to racial injustice (King, 1964, p. 18). Such delays, as King notes, are explicit political tactics by those seeking to preserve the undemocratic status quo whether by litigation (King, 1964, p. 70) or by the Dixiecrats' obstruction in Congress (King, 1964, p. 150). The last point in particular raises questions about delays built into representative democracy: absent democratic justice, institutionalized slowness benefits the forces of an unjust status quo, and thus amounts to imposed patience.

\section{Mortal Condition}

Centuries of delays are outrageous enough - but even worse in light of the limited human lifespan. Individuals who experience injustice simply do not have much time to wait. Human mortality thus contributes to democratic impatience. While Cornel West is correct in noting how the Christian belief in 'personal immortality' is central for King's religious orientation (West, 1999, p. 430), secularization has changed our relation to time such that awareness of mortality has become more central (Fenn, 2001, p. 65). This change manifests itself when King invokes human mortality to explain democratic impatience. Ordinary individuals attended the 1963 March on Washington 'to achieve democracy in their time' (King, 1964, p. 123; emphasis added). They did not strive for full democracy at some future point in time, but 'in their time' - in their lifetime. Democratic impatience, hence, derives from an awareness of the finite span of time each of us has. Democratic impatience is a temporal disposition for mortals, which is why it is no surprise that King would find that 'It had adherents of every faith, members of every class, every profession, every political party, united by a single ideal' (King, 1964, p. 123).

King illustrates the democratic rather than self-regarding potential of a recognition of human mortality in his discussion of an African American teenager's decision to join the protests, despite his father's prohibition: 'For, you see, I'm not doing this only because I want to be free. I'm doing it also because I want freedom for you and Mama, and I want it to come before you die' (King, 1964, p. 98). This teenager would have had a lifetime of opportunities for action. He could have waited to experience justice later in his life. Instead, he is driven to democratic impatience by awareness that those he cares about are closer to death. He feels their greater urgency because he recognizes their mortality.

King also believes that awareness of our shared mortality should prompt those not personally affected by injustice to identify with the democratic impatience of the aggrieved. All of us are mortal. Recognizing this shared humanity helps each of us understand and share in others' respective democratic impatience. In particular, 
King seeks to convince those championing gradual change that they are making arguments not commensurate with the human condition: 'What they do not realize is that it is no more possible to be half free than it is to be half alive' (King, 1964, p. 128). In effect, advocates of patient change defend an unnatural, hybrid form of existence - that of being half-dead. Similarly, King believes that to deny immediate full equality to African Americans amounts to denying them full birth: 'I would like to ask those people who seek to apportion to us the rights they have always enjoyed whether they believe that the framers of the Declaration of Independence intended that liberty should be divided into installments, doled out on a deferredpayment plan. Did not nature create birth as a single process' (King, 1964, p. 128)? To King, rights discourse - the claim of inborn rights - thus commits all of us to democratic impatience. King demands full life and thus full equality for African Americans because being half-born is just as unnatural as being half-dead. An awareness of our mortality requires us to want everyone to by fully alive and requires us to become democratically impatient on each other's behalf.

\section{Social Acceleration}

While Why We Can't Wait was written before some of the developments that define contemporary social acceleration, it nonetheless explains how the newly possible rapidity of modern politics, economy, and technology facilitates democratic impatience. By invoking social acceleration, King draws on a third temporal origin to complement the other two in accounting for democratic impatience.

While centuries of injustice as well as human mortality could have served as vehicles for democratic impatience at earlier points in time, the particular context of a rapidly changing age provides a new impetus for democratic impatience. In particular, King clarifies that African Americans' democratic impatience draws on the possible speed of political and economic progress in the contemporary age:

The American Negro ... realized that just thirty years ago there were only three independent nations in the whole of Africa. He knew that by 1963 more than thirty-four African nations had risen from colonial bondage. ... Witnessing the dramatic change of Negro progress elsewhere in the world, witnessing a level of conspicuous consumption at home exceeding anything in our history, it was natural that by 1963 the Negro would rise with resolution and demand a share of governing power, and living conditions measured by American standards rather than by the standards of colonial impoverishment. (King, 1964, p. 22)

In his 'Letter from Birmingham City Jail,' King further dramatizes this international context for democratic impatience: 'The nations of Asia and Africa are moving with jetlike speed toward the goal of political independence, and we still creep at horse and buggy pace toward the gaining of a cup of coffee at a lunch

(c) 2016 Macmillan Publishers Ltd. 1470-8914 Contemporary Political Theory Vol. 16, 3, 363-386 
counter' (King, 1991b, p. 292; emphasis added). Decolonization thus illustrates the feasibility and the reasonableness of democratic impatience: unjust and deeply entrenched political structures can be swept away quickly. In making this argument, King simultaneously invokes rapid changes in the economy and faster transportation technologies.

Contrary to Mahatma Gandhi, who defends a patient model of political change against modern technology's immoral speed (Mehta, 2011), King turns to modern technology to describe the task of the civil rights movement. For example, King believes that '[a]s a beginning it is important to X-ray our history and reveal the full extent of the disease' (King, 1964, p. 119). Eschewing Gandhi's organic metaphors, King suggests that the civil rights movement 'accelerated in geometric proportions' (King, 1964, p. 118). To explain the success of mass protests, King makes an analogy to the very recent medium of television: "As the broadcasting profession will confirm, no shows are so successful as those which allow audience participation' (King, 1964, p. 39). Importantly, King credits television both for sparking civil rights protests (King, 1964, p. xi) and for reshaping American public opinion. Television transcended the physical limitations of geography in general and of segregation in particular, as it allowed a national audience - including whites - to witness the 1963 March of Washington and be changed by it (King, 1964, pp. 124-125).

But King does not fetishize technological change, nor does he render it an unproblematic model for democratic politics. To begin with the latter, King distances himself from technological conceptions of politics: political change is harder and less predictable than 'pressing a row of buttons. Human beings with all their faults and strengths constitute the mechanism of a social movement' (King, 1964, p. 43). More importantly, King worries about the dangers of technological innovation. Due to rapid technological progress, humanity now has the means for nuclear self-annihilation (King, 1964, p. 139). King also identifies a more immediate threat to human well-being, namely the loss of low-skilled jobs as a result of increasing automation (King, 1964, p. 139; 1991a, p. 203).

Importantly, King believes that both social acceleration's dangers and benefits foster democratic impatience, which makes it especially timely today. While television may illustrate social acceleration's newfound opportunities, automation highlights the dangers of waiting any further with respect to democratic transformation. Automation is bound to worsen racial injustice: 'The Negro's economic problem was compounded by the emergence and growth of automation. Since discrimination and lack of education confined him to unskilled and semiskilled labor, the Negro was and remains the first to suffer in these days of great technological development' (King, 1964, p. 24). Technologically driven, rapid changes in the economy threaten to further entrench racial injustice. Thus, democratic impatience follows from the costs of social acceleration. Accordingly, even if social acceleration has intensified since King's days, this would make 
democratic impatience more and not less relevant for the contemporary world. We need democratic impatience precisely because existing injustices will deepen and new forms of injustice arise due to contemporary social acceleration.

\section{Operational Patience}

The previous section established that King's democratic impatience has multiple, mutually reinforcing temporal origins. Democratic impatience thus constitutes a more profound temporality than commonly assumed. The present section expands on the sophistication of democratic impatience's temporal nature by explaining how democratic impatience contains operational patience within itself. This operational patience differs from what I noted earlier, namely that democratic impatience sustains itself for as long as individuals suffer from imposed patience. Operational patience performs a different function: it facilitates strategic delays; moreover, it maintains a long-term process of transformation. Democratic impatience is thus patient in ways that productively complicate our thinking.

Why We Can't Wait - notwithstanding the title - appreciates strategic delays and proposes long-term processes of transformation. Both may at first blush appear to be in tension with the call for impatience. Indeed, adherents of patience might point to these 'patient' moments to suggest that King turns to patience because impatience falters on its own. If patience needs to come to the rescue of impatience, then patience would be the more important of the two. However, King did not write How We Wait Right. Adherents of patience merely prove here that they tend to latch onto patient aspects of democratic impatience to make patience the dominant factor, simply because they cannot entertain the possibility that impatience is a virtue (Callan, 1993, pp. 538, 523; Kupfer, 2007, pp. 269, 266). Importantly, they disavow the potential complementarity of impatience and patience due to mistakenly assuming that these temporalities are mutually exclusive.

King's unconventional inclusion of patience within democratic impatience reveals the inadequacy of not only our philosophical distinctions, but also of our language. The very terms seem to get us stuck. When it comes to 'impatience,' the prefix 'im-' has been understood to solely indicate a negation of the word 'patience' that it modifies. That said, the Oxford English Dictionary explains that the prefix 'im-' derives from 'in-' (OED, 2015a), which denotes 'into, in, within; on, upon; towards, against' (OED, 2015b). If we substituted 'in-patience' for 'im-patience' - a potentially inaudible difference (Derrida, 1982, pp. 4-6) - then another possibility would emerge, namely that both patience ('within') and its negation ('against') potentially coexist with each other in 'impatience.' Impatience might thus be more temperate than its various definitions suggest, an insight reflected in King's approach. 'Im/patience' would be one possible way to represent this coexistence of the two temporalities. But 'im/patience' does not fully describe King's theory because it does 
not sufficiently characterize the relationship between the two temporalities. Critically, for King, impatience is primary because it provides ethico-political guidance; conversely, any elements of patience are subordinate - they are designed to 'speed victory' (King, 1964, p. 96). Accordingly, I employ the term 'operational patience.' It reflects that patience is a subordinate, operational component in a process that is driven by democratic impatience. Operational patience is a subset of - not an alternative to, or abandoning of - democratic impatience.

One kind of operational patience concerns strategic delays regarding protests. King provides several examples of how civil disobedience - the clearest manifestation of democratic impatience, both for rejecting imposed patience and for pursuing democratic transformation - involves strategic delays. First, King describes how civil rights protests were carefully planned in advance: they resulted from drawn-out processes of information-gathering, decision-making, training, and preparation of logistics (King, 1964, pp. 53-58). Second, protests were gradually rolled out because 'in hardcore communities a more effective battle could be waged if it was concentrated against one aspect of the evil and intricate system of segregation' (King, 1964, p. 54). It would have been self-defeating to immediately extend the protests to all the institutions that were to be transformed. Third, King discusses the gradual roll out also as a way of ensuring stamina and of building momentum (King, 1964, p. 60). Fourth, nightly church meetings served to recruit further protesters, who had to come back for training on subsequent days (King, 1964, pp. 60-62). New recruits could not simply rush from a meeting to a protest; delay was built into recruitment to forestall instant gratification. Finally, King notes how leaders of the Birmingham civil rights protests delayed planned actions in response to changing conditions (King, 1964, p. 65).

The pursuit of long-term processes of social transformation constitutes a second kind of operational patience. As King explains, we must not confuse democratic impatience with 'unplanned spontaneity' (King, 1964, p. 129). Instead 'Solutions to the complex plight of the Negro will not be easy. ... [W]e have no magic. We will make progress if we accept the fact that four hundred years of sinning cannot be canceled out in four minutes of atonement' (King, 1964, p. 130). 'Unplanned spontaneity' would not be commensurate with the complex problems at hand, and as such would fail to create justice. Democratic impatience, hence, appreciates that it will take time to achieve the desired social transformation. Critically, King indicates that conflating democratic impatience with 'unplanned spontaneity' would greatly reduce society's obligation to rooting out injustice because it would create the mistaken impression that it could be accomplished in 'four minutes.' Democratic impatience must not provide an excuse for half-hearted programs. In asserting that democratic impatience commits us to long-term transformation, King furthermore prevents those who have to atone for racial injustice from misappropriating the mantle of democratic impatience: to wish to quickly bring to conclusion policies that create racial and economic justice does not reflect democratic impatience - quite the opposite. 
The long-term programs of transformation King has in mind are designed to overcome the ongoing effects of centuries of racial injustice (King, 1964, p. 134). Democratic impatience therefore aims to speed up our distancing ourselves from past injustice. It builds on impatient knowledge to offer a concrete plan for how to overcome injustice. King terms his proposal a 'Bill of Rights for the Disadvantaged, our veterans of the long siege of denial' (King, 1964, p. 139), which would involve concerted efforts to secure full employment and 'a social work apparatus on a large scale' to counter to debilitating social consequences of centuries of oppression (King, 1964, p. 139). While all of these measures would certainly have long-term benefits, King believes that they 'would immediately transform the conditions of Negro life' by infusing African Americans with a sense of possibility, which itself would contribute to a myriad of advancements (King, 1964, p. 138). Indeed, a clear, national commitment to creating meaningful material equality for African Americans would greatly accelerate the kinds of social transformations that normally take a long time: 'Change in human psychology is normally a slow process, but it is safe to predict that, when a people is ready for change as the Negro has shown himself ready today, the response is bound to be rapid and constructive' (King, 1964, p. 138). That is, the pace of change would be commensurate with the democratic impatience that propelled it - even as we need operational patience to sustain a program of transformation for as long as necessary.

\section{Conclusion}

King's democratic impatience improves democratic theory in a number of ways. He shows that democratic impatience can achieve the same democratic ends otherwise attributed to patience. In particular, democratic impatience overcomes undemocratic legacies, constitutes democratic subjectivity and agency, ensures political accountability, and creates a more inclusive practice of democratic belonging. While representative, deliberative, and radical democrats praise patient deliberation's contributions to these democratic ends, King instead turns to impatient knowledge, because the latter does not depend on an ideally democratic starting point. Moreover, King worries that under non-ideal circumstances democratic patience may - inadvertently - amount to imposed patience, that is, may inadvertently perpetuate the unjust status quo. Contrary to radical democrats, King believes that impatience manifests as well as creates democratic subjectivity and agency. Unlike radical democrats, he regards impatience as providing the necessary impetus and direction for democratization. True, King acknowledges the role that operational patience plays for effective political action and long-term processes of transformation. However, in a productive complication of our (theoretical) vocabulary, King articulates operational patience as a subset of democratic impatience.

(c) 2016 Macmillan Publishers Ltd. 1470-8914 Contemporary Political Theory Vol. 16, 3, 363-386 
My interpretation of King has stressed his contributions to democratic theory as such. This may incur objections concerning the broader use of his situated thinking. Although King formulates his democratic impatience in the specific context of US slavery, segregation, and racism, he makes clear that his situated thinking produces a concept that applies to democratic temporality and justice broadly speaking. On the one hand, King does this by relating African Americans' to workers' democratic impatience, as well as to the impatience of the colonized. On the other hand, two of the temporal origins he provides - mortality and social acceleration can extend the concept of democratic impatience to political movements that do not mirror the centuries of oppression suffered by African Americans. Democratic subjects may be warranted in their impatience when their grievances are exacerbated by their limited lifetime, or when delays in redressing these grievances are out of sync with the pace of contemporary life.

A related objection regarding King's situated thinking would emphasize that he was not fighting for justice within democracy - but to create democracy where there was none (King, 1991b, p. 294). Conceptually, democratic impatience might be limited to the transition from non- or perhaps quasi-democracy to democracy. However, I think that King's concept pertains to ordinary democracy for a number of reasons. First, the transformative context facilitates conceptual clarity. When King demonstrates the vital contribution that democratic impatience can make to creating democracy, it is easier to see why democratic impatience might be useful for enhancing established democracies. Furthermore, King's idea that representatives need to be accountable to democratic impatience suggests a broader application than founding moments - it can foster citizen involvement in ordinary politics, which would strengthen democracy. Moreover, likening the democratic impatience of the civil rights to that of the labor movement indicates that King's concept does not depend on an absence of democracy, as white workers did not experience the same degree of undemocratic exclusion. Democratic impatience redresses different kinds and degrees of injustice. Finally, democratic impatience applies to ordinary democracies insofar they contain many injustices, large or small: 'the time is always right to do right. Now is the time to make real the promise of democracy' (King, 1991b, p. 296). In other words, democratic impatience remains necessary within ordinary democracies precisely because democracy and justice are incomplete - remain aspirational.

In improving democratic theory's conceptualization of democratic temporality, King's democratic impatience also changes our perspective on contemporary social acceleration. He shows that the very dangers of an increasingly accelerated world impel us to act in those areas where our democracies are flawed, insufficient, or unjust - as social acceleration would otherwise deepen respective democratic deficits. If contemporary social acceleration creates worse dangers than in King's time - for example, capitalism's recent acceleration generates new economic crises, deepens existing injustices, and speeds up catastrophic climate change - then this 
only affirms our need for democratic impatience. In short, we must embrace impatience as $a$ democratic virtue.

\section{Acknowledgments}

The author wishes to thank Doug Dow, Lisa Ellis, Diana Judd, Jill Locke, Char Miller, Alexander Moon, and Ella Myers for their insightful questions and comments on earlier versions. The author is also grateful to Sam Chambers and the anonymous reviewers for their generosity, and for their incredibly helpful recommendations.

\section{About the Author}

Mario Feit is Associate Professor of Political Theory at Georgia State University. His recent publications include essays on Thomas Paine and Sheldon Wolin, as well as a book entitled Democratic Anxieties: Same-Sex Marriage, Death, and Citizenship. This essay is part of an ongoing book project that seeks to recover impatience as a democratic virtue.

\section{Note}

1 The 'Letter' appears as chapter 5 of Why We Can't Wait. Since the standalone 'Letter' is more widely cited, I refer to it rather than to chapter 5.

\section{References}

Agacinski, S. (2003) Time Passing. Modernity and Nostalgia. New York: Columbia University Press. Augustine (1952) Patience. In: Treatises on Various Subjects. Washington, DC: Catholic University of America Press, pp. 235-264.

Bauman, Z. (2005) Liquid Life. Cambridge, UK: Polity Press.

Berry, E. (2005) Doing time: King's 'Letter from Birmingham Jail'. Rhetoric and Public Affairs 8(1): $109-132$.

Callan, E. (1993) Patience and courage. Philosophy 68(266): 523-539.

Cohen, J. (1997) Deliberation and democratic legitimacy. In: J. Bohman and W. Rehg (eds.) Deliberative Democracy: Essays on Reason and Politics. Cambridge, MA: MIT Press, pp. 67-91.

Coles, R. (2005) The wild patience of radical democracy: Beyond Žižek's lack. In: L. Tønder and L. Thomassen (eds.) Radical Democracy. Politics Between Abundance and Lack. Manchester, UK: Manchester University Press, pp. 68-85.

Coles, R. (2008) Of tensions and tricksters: Grassroots democracy between theory and practice. In: Christianity, Democracy, and the Radical Ordinary. Conversations Between a Radical Democrat and a Christian. Eugene, OR: Cascade Books, pp. 277-308.

Connolly, W.E. (2002) Neuropolitics: Thinking, Culture, Speed. Minneapolis, MN: University of Minnesota Press.

Crary, J. (2013) 24/7. Late Capitalism and the Ends of Sleep. London: Verso.

384 (C) 2016 Macmillan Publishers Ltd. 1470-8914 Contemporary Political Theory Vol. 16, 3, 363-386 
Dean, J. (2009) Democracy and Other Neoliberal Fantasies. Communicative Capitalism and Left Politics. Durham, NC: Duke University Press.

Dean, J. (2010) Blog Theory. Feedback and Capture in the Circuits of Drive. Cambridge, UK: Polity Press.

Derrida, J. (1982) Margins of Philosophy. Chicago: University of Chicago Press.

Fenn, R.K. (2001) Time Exposure. The Personal Experience of Time in Secular Societies. Oxford: Oxford University Press.

Fisher, P. (2002) The Vehement Passions. Princeton, NJ: Princeton University Press.

Garrett, S.R. (1999) The patience of job and the patience of Jesus. Interpretation: A Journal of Bible and Theology 53(3): 254-264.

Glezos, S. (2012) The Politics of Speed. Capitalism, the State and War in an Accelerating World. London, UK: Routledge.

Goodwyn, L. (1981) Organizing democracy: The limits of theory and practice. Democracy: A Journal of Political Renewal and Radical Change 1(1): 41-60.

Grattan, L. (2014) Populism and rebellious cultures of democracy. In: R. Coles and M. Reinhardt (eds.) Radical Future Pasts: Untimely Political Theory. Lexington, KY: University Press of Kentucky, pp. 179-216.

Gutmann, A. and Thompson, D. (2004) Why Deliberative Democracy? Princeton, NJ: Princeton University Press.

Hanchard, M. (1999) Afro-modernity: Temporality, politics, and the African diaspora. Public Culture 11(1): 245-268.

Harvey, D. (1990) The Condition of Postmodernity. An Enquiry into the Origins of Cultural Change. Cambridge, MA: Blackwell.

Kaster, R.A. (2002) The taxonomy of patience, or when is Patientia not a virtue? Classical Philology 97: 133-144.

King, M.L. (1964) Why We Can't Wait. New York: Penguin.

King, M.L. (1991a) If the negro wins, labor wins. In: J.M. Washington (ed.) A Testament of Hope. The Essential Writings and Speeches of Martin Luther King, Jr. San Francisco: HarperSanFrancisco, pp. 201-207.

King, M.L. (1991b) Letter from Birmingham City Jail. In: J.M. Washington (ed.) A Testament of Hope. The Essential Writings and Speeches of Martin Luther King, Jr. San Francisco: HarperSanFrancisco, pp. 289-302.

King, M.L. (1991c) Playboy interview: Martin Luther King, Jr. In: J.M. Washington (ed.) A Testament of Hope. The Essential Writings and Speeches of Martin Luther King, Jr. San Francisco: HarperSanFrancisco, pp. 340-377.

Kupfer, J.H. (2007) When waiting is weightless: The virtue of patience. The Journal of Value Inquiry 41: 265-280.

Lauber, D. (2010) The redeeming patience of Jesus. Theology Today 67: 320-334.

Madison, J., Hamilton, A. and Jay, J. (2005) In: J.R. Pole (ed.) The Federalist. Indianapolis, IN: Hackett Publishing.

Mehta, U.S. (2011) Patience, inwardness, and self-knowledge in Gandhi's Hind Swaraj. Public Culture 23(2): 417-429.

Miller, J.P. (2012) Caring to disagree: Democratic disagreement as civic care. Polity 44(3): 400-425.

Morgan-Olsen, B. (2013) A duty to listen: Epistemic obligations and public deliberation. Social Theory and Practice 39(2): 185-212.

OED. (2015a) im-, prefix1. OED Online. http://www.oed.com/view/Entry/91616. Accessed 14 May 2016.

OED. (2015b) in-, prefix2. OED Online. http://www.oed.com/view/Entry/92973. Accessed 14 May 2016.

Rosa, H. (2005) The speed of global flows and the pace of democratic politics. New Political Science 27(4): 445-459. 
Rosa, H. (2010) Alienation and Acceleration. Towards a Critical Theory of Late-Modern Temporality. Malmö, Sweden: NSU Press.

Scheuerman, W.E. (2004) Liberal Democracy and the Social Acceleration of Time. Baltimore, MD: Johns Hopkins University Press.

Shapiro, I. (2002) Optimal deliberation? Journal of Political Philosophy 10(2): 196-211.

Shulman, G. (2008) American Prophecy. Race and Redemption in American Political Culture. Minneapolis, MN: University of Minnesota Press.

Svendsen, L. (2005) A Philosophy of Boredom. London, UK: Reaktion Books.

Tertullian. (1959) Patience. In: Disciplinary, Moral, and Ascetical Works. New York: Fathers of the Church, pp. 191-222.

Urbinati, N. (2006) Representative Democracy. Principles and Genealogy. Chicago: University of Chicago Press.

Weiner, G. (2012) Madison's Metronome. The Constitution, Majority Rule, and the Tempo of American Politics. Lawrence, KS: University of Kansas Press.

West, C. (1999) Prophetic Christian as organic intellectual: Martin Luther King, Jr. In: The Cornel West Reader. New York: Basic Civitas Books, pp. 425-434.

Wolin, S. (1994). Norm and form: The constitutionalization of democracy. In: J.P. Euben, J.R. Wallach and J. Ober (eds.) Athenian Political Thought and the Reconstruction of American Democracy. Ithaca, NY: Cornell University Press, pp. 29-58.

Wolin, S. (1997) What time is it? Theory and Event 1(1).

Wolin, S. (2008) Democracy Incorporated: Managed Democracy and the Specter of Inverted Totalitarianism. Princeton, NJ: Princeton University Press.

Young, I.M. (2000) Inclusion and Democracy. Oxford: Oxford University Press. 